IRSTI 03.61 .00

\author{
Galiev A.A. ${ }^{1}$, Batkalova K.M. ${ }^{2}$, Yugay M.R. ${ }^{3}$ \\ ${ }^{1}$ Professor, Dr., e-mail: galiev_anuar@mail.ru \\ ${ }^{2}$ Doctorate-student, e-mail: kuralai07@gmail.com \\ ${ }^{3}$ Doctorate-student, e-mail: m.yugay83@hotmail.com \\ Al-Farabi Kazakh National University, Kazakhstan, Almaty

\section{TRADITIONAL MECHANISMS OF ETHNO-CULTURAL IDENTITY CONSTRUCTION IN JAPAN: LIFE CYCLE CUSTOMS AND RITUALS}

\begin{abstract}
This paper considers the mechanisms of formation of ethnocultural identity of Japanese people in the process of conducting traditional life cycle customs and rituals. Based on the analyses of basic elements and symbolic content of life-cycle rituals of Japanese people, we determine the role and functions of rites of passage in traditional Japanese culture, as well as the relation between archaic and modern elements of such rituals, including nowadays changes in its perception and interpretation. Study results showed that symbols and signs enclosed in life-cycle rituals and related customs not only enable identification of individuals with specific community, but also serve as an archiving tool for maintenance and continuity of national values and cultural-specific knowledge that have been accumulated over the historical development of the whole Japanese society.
\end{abstract}

Key words: ethnic identity, life cycle customs and rituals, national code, traditional culture.

\author{
Галиев А.А. ${ }^{1}$, Батқалова Қ.М. ${ }^{2}$, Югай М.Р. ${ }^{3}$ \\ ${ }^{1}$ профессор, Аоктор, e-mail: galievanuar@mail.ru \\ ${ }^{2} \mathrm{PhD}$ студент, е-mail: kuralai07@gmail.com \\ ${ }^{3} \mathrm{PhD}$ студент, e-mail: m.yugay83@hotmail.com \\ әл-Фараби атындағы Қазақ ұлттық, университеті, Қазақстан, Алматы қ.
}
Жапониядағы этно-мәдени бірегейлікті қалыптастырудың Аәстүрлі механизмдері: өмірлік циклге байланысты әдет-ғұрыптар мен салт-дәстүрлер

Бұл мақалада жапон халқының этномәдени бірегейлігін қалыптастыру тетіктері аАамның өмірлік цикліндегі әдет-ғұрыптар мен салт-дәстүрлер негізінде қарастырылған. Өмірлік циклінің салт-жораларында кездесетін басты элементтердің символикалық мәні мен мазмұнын та^дау негізінде дәстүрлі жапон мәдениетінде адам өміріндегі өтпелі кезеңге қатысты әдет-ғұрыптардың рөлі мен функциялары, сондай-ақ архаикалық және заманауи салт-дәстүрлер арасындағы байланыс, оның ішінде оларды қабылдау мен түсіндіруде орын алған өзгерістер анықта^ды. Зерттеу нәтижелері өмірлік циклге байланысты салт-дәстүрлер мен әдет-ғұрыптар нақты бір қауымластық өкілдерінің өзара бірегейлігін анықтауға мүмкіндік беріп қана қоймай, сондай-ақ жапон халқының тарихи дамуы барысында жинақталған мәдени құндылықтар мен мәдени білімнің үздіксіздігін қамтамасыз ету құралы ретінде қызмет ететіндігін айғақтады.

Түйін сөздер: этномәдени бірегейлік, өмірлік цикл рәсімдері, ұлттық коА, Аәстүрлі мәдениет. 


\author{
Галиев А.А. ${ }^{1}$, Баткалова К.М. ${ }^{2}$, Югай М.P. ${ }^{3}$ \\ ${ }^{1}$ профессор, Аоктор, e-mail: galievanuar@mail.ru \\ ${ }^{2}$ PhD студент, e-mail: kuralai07@gmail.com \\ ${ }^{3} \mathrm{PhD}$ студент, e-mail: m.yugay83@hotmail.com \\ Казахский национальный университет им. аль-Фараби, Казахстан, г. Алматы \\ Традиционные механизмы \\ формирования этнокультурной идентичности в Японии: \\ обряды и ритуалы жизненного цикла
}

\begin{abstract}
Аанная статья выявляет механизмы формирования этнокультурной идентичности японского народа в процессе осуществления традиционных обрядов и ритуалов жизненного цикла. На основании анализа символического содержания обрядов жизненного цикла определены роль и функции обрядов перехода в традиционной японской культуре, а также связь межАу архаичными и современными элементами обрядов, вк^ючая изменения в их восприятии и интерпретации. Результаты исследования показали, что ритуалы жизненного цикла и связанные с ними обычаи не только позволяют отождествлять людей с определенным сообществом, но и служат инструментом обеспечения преемственности культурных ценностей и специфических культурных знаний, накопленных в течение всего исторического развития японского народа.

Ключевые слова: этнокультурная идентичность, обряды перехода, национальный код, традиционная культура.
\end{abstract}

\section{Introduction}

The process of ethnocultural identification of a person is carried out throughout one's life. Therefore, traditional customs and rituals of the life cycle are one of the key mechanisms for the formation of ethno-cultural identity, including the Japanese people.

The identification process acts as a socio-and psycho-cultural mechanism that forms the core of the personality and harmonizes the relationship of the person with the social environment, contributing to the immersion of the person into the world of cultural values and the organic development of the dominant type of national mentality. Identification sets anthropological priorities and norms, forms images of a person and humanity, which are recognized as acceptable and desirable within the framework of certain ethnocultural community (Chebonenko, 2007). Identification allows one to feel their belonging to a particular social group, community, which is the carrier of cultural values. The means of identification are socio-cultural patterns (values, norms, ideals, etc.).

The essence of ethnocultural identity is a synthesis of sensory-instinctive (a complex of feelings and emotional experiences about belonging to «own» ethnocultural community), rational (a set of reflexive processes unfolding in time, forming ethnic / national identity) and mental (latent, deep layer of ethnocultural identity, formed by the culture-specific vision and perception of the world) components. Self-consciousness, feelings and mentality form the behavioral aspect of ethnocultural identity (Malygina, 2005).

In order for the sensory-instinctive, rational and mental components in unity to contribute to the formation of the behavioral aspect of the ethnocultural identity of the individual (historical and cultural-conditioned forms of representation and manifestation of belonging to the ethnocultural community and its unity and integrity (Malygina, 2005), many traditional cultural means are used in the process of formation of ethnocultural identity the national language, literature, customs, holidays, etc.

The life cycle customs and rites ritually marks a person's transition from one status (from one role, phase of life, or social status) to another. Classic parts of life cycle rituals include main three stages as: separation - the first stage of a Rite of Passage in which individuals are removed from their community or status (separation from normal life); liminal - the stage of a ritual, particularly of a Rite of Passage, in which one has passed out of an old status but not yet entered a new one (on threshold) state of between; and reincorporation - the third phase of a rite of passage during which participants are returned to their community with a new status (reincorporation into society with new status) (Van Gennep, 2004). Different cultures around the world have rites of passage, and they follow a similar patterns corresponding with important events in human life, like birth, adulthood, marriage, eldership and death. 


\section{Research Methodology}

Paper examines the mechanisms of ethnocultural identity formation in the example of traditional life cycle customs and rituals in Japanese culture from the perspective of Semiotic Method. Semiotics is a study of signs, symbols and significations. The sign systems of traditional customs and rituals, including the Rites of Passage, ensure transmission of cultural values and information between and within generations. Authors distinguish three aspects of sign content of Rites of Passage: syntactic (formal relation of signs within a sign system); semantics (symbolic content of signs); and pragmatics (relations of the sign to the receiver, interpreter).

\section{Childbirth Rites}

Traditional birth related rituals and customs can be divided into the following components: prematernity customs and beliefs; childbirth rites and socialization ceremonies. Japanese people have its unique ritual to welcome children into the world and integrate them into the community.

Japanese birth related ceremonies are rich of magical and rational components, as praying to the souls of ancestors and the manufacture of amulets, as well as the use of traditional medical knowledge. It is believed that the child begins to live four months before actual birth, i.e. when the soul tamashii appears. That is why even nowadays the age of Japanese people often counted not from the date of their actual birth, but since the moment of the «invasion of the soul» (Bethel, 1992).

First Celebration that takes place during pregnancy is called Obi-iwai - celebration of the maternity band. During the Edo Period (16031867), in which infanticide was common, it was forbidden to practice abortion after the celebration of this ceremony.

Usually this ceremony is held on Dog's Day, because dogs are said to have an easy delivery. Rice cakes may also be distributed this day, as an announcement of the expected birth.

Japanese birth customs include the special rites for an easy childbirth that is conducted by praying for O-Jizō-Sama or Jizō-san and Kannon Bodhisattva, asking for an easy delivery and easy child-birth. It is believed that the Ubu-Gami, the God of Birth will bring the tama - the soul of a child at the moment of birth.

In ancient Japan, a special birthing hut - Ubuya was constructed within the hamlet and new mothers stayed there for 30 days after giving birth.
This custom is rooted on the Folk perception of pollution.

On seventeenth day a new-born Japanese bodies are believed to embody godliness, that is why they are dressed completely white. White color symbolizes clean and untarnished state. After the 17 th days in age, baby is finally believed to be actual child, rather than gods. When this happens, they make the transition from white attire for different colors.

One of the symbolic rite in Japanese culture is related to the conserving of the umbilical cord. This cord is thought to have a strong link to the wellbeing of the babies, that is why Japanese parents look after them so carefully.

Birth rites in Japanese culture also include the recuperation stage that constitute an important ritual following the child birth in Japan, when new Japanese mothers often return to their parents' home for a month.

\section{Socialisation ceremonies}

First rite of socialization is presented by celebration of O-Sichiya that means a naming ceremony and introduction to the community, and it takes place roughly a week after the new-born enters the world. Once the babys name is decided, the father will have it handwritten in Japanese calligraphy on the Meimeisho, a so called name certificate. The Meimeisho can be in a different form (scroll, poster and etc.) and it is usually displayed in the house.

Relatives and friends will gather around the whitely dressed newborn and present their gifts or Shugibukuro - a monetary gift in a special envelope. Then the celebratory dinner is served, which compulsorily include two symbolical dishes:

Sekihan - a red rice and Tai - sea bream. In Japan, people has been considered that color of red is a lucky color because it associates with the color of the sun, what about the sea bream, the Japanese word for sea bream, tai, sounds similar to the word «mede-tai» (happy, festive, good luck, auspicious). The color of sea bream is also red, so it has been thought fish of felicity and a necessity for dishes for happy events like naming ceremony. Thus, Naming Ceremony is one of the major celebrations in the life-cycle rites, since the name defines a status of the child in the community of people and is considered to be one of the essential symbols, that distinguish the child from the world of spirits. Therefore, in the first week of its life the child gradually receives the signs of belonging to the social community: first cloth, name and token gifts. 
Then follows a Miamairi ceremony - a first Shrine visit, conducted usually a month after the birth, and this rite represents the end of a period when the mother is regarded as polluted. This ceremony is marked with distribution of small gifts of thanks to relatives and neighbors.

Approximately 100 days after the birth, Japanese families conduct a ceremony of kuizome, which means a ritual weaning, when the baby is served a taste of the food, having symbolic meaning of longlife, prosperity and well-being.

In ancient Japan people celebrated Boys' day and Girls' Day separately. The Boys' day was called Tango no Sekku, and was celebrated on the 5th day of the 5th moon in the lunar calendar or Chinese calendar. After Japan switched to the Gregorian calendar, the date was moved to May 5 .

While Girls' Day called Dolls festival Hinamatsuri was celebrated on March 3. In 1948, the government declared this day as a national holiday to celebrate the happiness of all children and to express gratitude toward mothers. Therefore, the holiday was renamed as Children's Day - Kodomo no Hi.

This days celebrations involved the raising of the carp-shaped flags called koinobori. Carp is closely related to the Japanese national identity and has a deep meaning. It signifies perseverance, due to the fish's ability to swim upstream, never stop moving, and resist simply «going with the flow» (Lebra, 1992).

Japanese families generally start to display the dolls in February and take them down immediately after the festival. According to folk beliefs leaving the dolls for a longer period after the end of festival will result in a late marriage for the daughter.

\section{First Birthday celebration}

Japanese culture pays a strong attention to the first Birthday of a child, that marks the learning to make first steps. In ancient Japan it was used to tie to the babys back a bag of rice to make it fall down, during this day Japanese families also made some predictions on babys future by making it choose certain object.

Japanese traditional culture has unique celebrations that mark the stage of children's growth and one of the brightest examples of such initiations is Shichigosan. This tradition has more than 300year history and constitute one of the milestones when the rites of passage were performed. In modern Japan Shichigosan ceremony is officially celebrated on November 15, when children visit the Shrine in traditional kimono for rites of protection and prayers for good fortune.

One can notice that the ceremony Shichigosan, which literally means the ages of 3-5-7 years, present only the odd numbers. According to folk beliefs odd numbers have a sacred meaning and bring good luck based on the yin-yang Chinese philosophy of feminine and masculine force. This ages mark the stage of children's growth.

During the ceremony parents usually ask a nearby shrine to perform a purification rite "Ohararai» and recite a Shinto prayer «Norito» for their children's strong health. The next symbolical rite being held during celebration of Shichigosan is a giving for a child a «chitose ame» - it is a long stick candy given to children celebrating Shichigosan. "Chitose ame» literally means 1,000-year candy and it comes as a pair of white and pink sticks, with symbolical colours indicating good luck, in a paper bag with symbols of longevity and good luck (Charles Peirce, 1940).

It should be noted here that the 3rd year of child is considered as particularly significant, which marks the start of new period in child's life. In middle ages, boys of aristocratic families wore hakama for the first time. Later on this ceremony was conducted at the age of 5, when Samurai children were introduced to Daimyo. The 5-year-old boy was called the Hakama-gi and wore the hakama (the male kimono).

The ceremony of Shichigosan also involved the rite of «Kamioki» - leaving hair, when boys and girls start growing out their hair. Folk belief states that diseases entered the body through the hair, and Japanese people would shave their children's hair until they reach 3 years old.

Additionally, Shichigosan ceremony include the rite of «Obotoki» when girls turned 7, parents celebrated the «obitoki» rite, in which their daughters went from using straps to secure their kimono to wearing obi.

Thus, the Shichigosan ceremony marks milestones in Japanese culture when rites of passage were performed for children.

\section{Rite of Marriage}

Shinto Wedding represent a traditional religious ceremony of Japanese culture. However, nowadays the wedding ceremony contain the elements of traditional Shinto style and western elements. In this paper we will particularly focus on traditional rite of marriage according to Shinto belief.

The current Shinto wedding ceremony is considered to be originated during in Taisho period. 
Shinto style wedding ceremony is full of symbolic elements ordered by special rite series. Wedding rite starts with sanshin ceremony, which literally means procession, when ritual musicians and a Shinto maiden lead the bride and groom and the other wedding participants to the shrine. Then follows the special rite of purification - shubatsu-no-gi. At the beginning of the ceremony, a Shinto priest begins the wedding ceremony by the purification ceremony of bride and groom, and all participants; after purification rite the priest announces their marriage to the gods or spirits (kami) of the shrine and asks for their blessing, this rite is called as Noritosoujou.

After the announcement of the marriage, a Shinto maiden dedicates a sacred dance to the kami - Kaguramai. Wedding ceremony includes also a special symbolical act called Chikai-no-sakazuki, when the bride and groom exchanges nuptial cups of the rice wine that was placed before the kami. This Japanese ritual is known as «san-san-kudo» and has a deep meaning. The rite «san-san-kudo» should be performed by the bride and groom and their parents; each of them drinks 3 times of sake from each of 3 cups. The first 3 represent three couples, the bride and groom, and their parents. The second 3 represent three human flaws: hatred, passion, and ignorance. If we look at the semantics of the term «san-sankudo», we can find that «ku», or 9 is a number that brings good luck according to folk belief, and «do» means deliverance from the three flaws stated above (Weddings in Japan, 20 July 2015).

Shinto style wedding ceremony then continues by seishi-soujou, when the groom reads out the marrige vow in Japanese and the bride and groom make offerings of tamagushi to the kami (Tamagushihairei) to vow their marriage. And finally, the young couple exchange of rings - yubiwa-no-gi and drinks the rice wine together (Shinzokuhai-nogi) by marking a strong bond between the couple's relatives, they share the rice wine dedicated to the kami.

Another symbolical component of the wedding ceremony is a rosary with 21 beads that represent the couple, their families and the Buddha all joined on one string to symbolize the union of the families. Wedding ceremony also involves honoring the parents with offers of flowers, a toast, or a letter expressing their love and gratitude. Additionally, it is common to decorate the Shrine with origami cranes, that symbolize a longevity and prosperity and usually 1,001 gold origami cranes are folded to bring luck, good fortune, longevity, fidelity, and peace to the marriage. Moreover, the dressing style of the bride also has a rich symbolical meaning.
Traditionally Japanese bride wears two kinds of wedding outfits: the shiro, which is a white kimono worn for the ceremony and the uchikake kimono which is a patterned brocade worn at the reception. The hair of the bride is worn in a bun with colorful kanzashi hair accessories. A white wedding hook called the tsuno kakushi finalizes the hair decoration for bride. This tsuno horns symbolizes obedience. The bride also carries a tiny purse (hakoseko), a small encased sword (kaiken), and a fan that is worn in the obi belt that represents happiness and a happy future (Edwards, 1989).

The wedding ceremony is followed by a feast, where different foods are served and all have special meanings, for example lobster might be served because red is a lucky color or clams served with both shells symbolize the couple's union.

Thus, we can observe that Japanese traditional wedding ceremony is a complex system of elements that include ritual acts, material objects of culture as well as folklore. Every act and ritual of the wedding ceremony is rich of symbolical meaning and deep functional meaning devoted to symbolically protect bride and groom as well as motivate certain culturally prescribed behavior of the newly marriage couple and their relatives. Moreover, the rites of marriage are devoted to the initiation of the bride and groom to the whole society in a new status as a newly formed family unit.

In recent years, western style wedding ceremonies have replaced traditional Shinto wedding rites. Most of the contemporary Japanese weddings present a combination of «traditional Japanese» and «Western» wedding elements, and this trend is playing a significant role in constructing modern Japanese cultural identity, by «elaborating multifaceted and highly commercializes» event in the life of modern Japanese people.

\section{Rite of Eldership}

Rite of Eldership in Japanese society has a very strong traditional value since the elders represent tradition and wisdom of the past, who as such possess the highest status in all societies and act as a role models for younger generation. In Japanese folk believe it is considered that elders become Ancestors, who link human and God together, and they are often called upon in times of need.

Japanese rites of eldership and ancestor worship is comprised of several birthday celebrations and mortuary traditions. In Japan people start to celebrate rite of eldership from ages 60 to 111, where each birthday celebration series are named accordingly, 
particularly 60th Birthday is a Kanreki celebration, the follows 70th Birthday - Koki, 77th - Kiju, 80th - Sanju, 88th - Beiju, 90th - Satsuju, 99th - Hakuju, 111th - Jooju.

Kanreki celebration (60th Birthday) marks first initiation to eldership. Moreover, it marks an auspicious occasion when two zodiac signs of elder's birth year - one in the 10-year cycle and the other in the 12-year cycle - converge again. According to Japanese believe, person who reaches the age of kanreki completes a full circle to attain «rebirth», and during such celebrations one may notice the elderly people's symbolical baby attire - red vest and red cup, like a new-born baby. In earlier times not many Japanese reached that age.

The series of special birthdays in Japanese tradition initiate people to different stages of old age. Therefore, it can be regarded as rites for eldership that are culturally guided by a society. We can witness how Japanese people continue to conduct Rites of Eldership even after the death of a certain family member. This is done in a tradition of Ancestor Worship.

\section{Rite of Ancestorship}

Ancestor worship is constituted of symbolic rituals as food offerings at the family altar to honor the spirit of ancestors. The offerings may include tea, rice, even flowers.

The next important component of Ancestor Worship is invitation of Priest from the family temple to chant a sutra on the monthly death anniversaries of ancestors. Where the Priest play the role of mediator between the family members and ancestors. Third element of ancestor worship is presented by the visits to a family grave, usually during the religious weeks marked by equinoxes and O-Bon festivals conducted in mid-summer. All these rites and customs are devoted to keep alive the memories of ancestors within a family. It should be noted here that memorial rituals for ancestor worship are highly integrated into Japanese daily life experience and still continues to be an important part of Japanese culture. Thus, memorial rituals play two main functions, as it helps to contribute in revealing and understanding one's origins, which constitutes a vital component of self-identity, also it helps to cope with the loss of a loved one and to realize the immortality of life as well as mitigate the pain of aging.

Japanese mortuary rites present a well-defined system of strong cultural guidance, where the perception of life is distinguished into three parts, like the life-transient state-afterlife. In Japanese tradition the nearness of death is symbolically marked by the rite of last water - Matsugo no Mizu, in which next of kin wet the lips of the dying person with water. Water symbolism is presented in almost every culture, for instance in Muslim tradition, the final debt of relatives before the dying person is to serve him/her with a drop of cold water (Holy Zamzam water or pomegranate juice), which quenches one's thirst. Japanese mortuary tradition includes following rites: a wake, a funeral, a cremation, a bone-picking ceremony, and east flowers. In Japan mortuary rituals continue every 7 days until the 49th day after death, and again on the 100th day. The 49th day ritual is considered as a «turning point», when it is believed that the spirit of the newly deceased (niibon) becomes a new Buddha (nii-Botoke) (Smith, 1974).

This rite is accompanied by special feast. After that follows periodic memorial rituals at the $1 \mathrm{st}$, 3rd, 7th, 13th, 17th, 23rd, 27th, 33rd and 50th death anniversaries. All these rites are devoted to ensure the right and smooth guidance of the deceased through different stages of spirit-new Buddha-Buddha, and consequently serve as a Rites of Passage to Ancestorhood. Social changes in modern Japanese society has its impacts on traditional ancestor worships and mortuary tradition of Japanese people as well as those who practice them, due to the fact that Japanese traditional family system has gone through many transformations.

Therefore, nowadays we can observe certain concerns in Japanese society about the possibility of diminishing the tradition of posthumous care because of great decrease of three-generation family system in Japanese society, which is considered to be the key condition for preserving an ancestral worship.

In addition, a growing number of people without patrilineal descendants also strengthen these social concerns. As it is known that the tradition of caring for the dead is closely connected to the Japanese ie system, however, we should note that the crucial role of family in ancestor worship has a political origin. Namely, the Meiji Civil Code (1898) specified the rule of succession by the eldest son, and the son stayed with his parents to form threegeneration family. The Civil Code also prescribed that ancestral rites, including altar and family grave be a part of ie which should be passed from generation to generation. Despite those changes and growing concerns Japanese people continue to strongly preserve and culturally guide Rites of Ancestorship. 


\section{Conclusion}

In essence, all the above-mentioned elements of life cycle customs and rituals of Japanese culture have a strong semiotic status and possess a significant place in Japanese society. In addition, initiation rites themselves possess an archetypical structure, for the same underlying patterns and procedures. The system of belief in symbolical death and re-birth is common for any culture, that share four main universal rites and rituals, including Japan: birth that signify the entrance to the life; coming of age that marks the adulthood; marriage that signify the entrance into a new life with a partner and finally, death that marks the stage when people enter the afterlife with the belief of re-birth. A sense of ethnic identity tends to increase with age and older group of society serve as main repositories of culture and cultural knowledge.

A question arises: What is the role of life cycle customs and rituals in constructing ethnic identity as a whole and why Japanese people continue to follow these rites and rituals from generation to generation?

Here would be our answer: an ethnic identity is a fundamental aspect of the self that includes a sense of membership in an ethnic group as well as attitudes and fillings with regard to that membership. We state that individuals confront their ethnicity for the first time through life cycle customs and rituals - Rites of Passage and related holidays. Moreover, symbols and signs enclosed in life cycle customs and related ceremonies not only enable identification of individuals with community, but also serve as an archiving tool for maintenance and continuity of cultural values and cultural-specific knowledge accumulated over the historical development of the whole Japanese society.

Thus, the life cycle customs, rituals and related national holidays with its culturally prescribed elements ensure a certain degree of persistence of core cultural values and beliefs of Japanese people.

\section{References}

«Weddings in Japan». Nippon.com. 20 July 2015.

Bethel, D.L. (1992). Life on Obasuteyama, or, Inside a Japanese Institution for Elderly. Lebra, T.K., ed., (1992). Japanese Social Organization. Honolulu. Hawaii: University of Hawaii Press.

Charles Peirce. (1940). The Philosphy of Peirce: Selected Writings, ed. Justus Buchler. London: Routledge and Kegan.

Chebonenko O.V. (2007). Kul'turno-simvolicheskij potencial regiona kak faktor formirovaniya kul'turnoj identichnosti molodezhi: Avtoref. diss... kand. kul'turologii. Sankt Peterburg.

Edwards, W. (1989). Modern Japan through Its Weddings: Gender, Person, and Society in Ritual Portrayal. Stanford: Stanford University Press.

Latyshev, I.A. (1985). Semeinaya zhisn yaponcev. Moscow.

Long, S.O. (2005). Final Days: Japanese Culture and Choice at the End of Life. Honolulu, Hawaii: University of Hawaii Press. Moskva.

Malygina I. V. (2005). Etnokul'turnaya identichnost': Ontologiya, morfologiya, dinamika: Avtoref. di d-ra filosof. Nauka.

Markaryan, S.B., Molodyakova, E.V. (1990). Prazdniki v Yaponii: obychai, obryady, socialnie funkcii.

Smith, R. (1974). Ancestor Worship in Contemporary Japan. Standford, Calif: Standford University Press.

Van Gennep, A. (2004) The Rites of Passage. Routledge. 